\title{
ASSYRIAN IDEOLOGY AND ISRAELITE MONOTHEISM
}

\author{
$B y$ BARUCH A. LEVINE*
}

Few subjects in the field of biblical and ancient Near Eastern studies have elicited as much attention in recent decades as the origin and development of Israelite-biblical monotheism. One needs more than the fingers of both hands to list the many collections of articles and individual monographs that treat this threshold in the history of religions. Attention shifts in the search for precursors from ancient Egypt to Mesopotamia, and in the West Semitic sphere, to Ugarit and the Middle Euphrates. It will be the burden of the present discussion, while providing requisite background, to focus on the Neo-Assyrian factor in the ongoing development of Israelite monotheism, rather than on the search for its ultimate origin, which may be beyond reach in the present state of knowledge.

More precisely, I will propose that the policies and campaigns of the Sargonids, especially of Sennacherib, who made Nineveh his political capital, elicited an Israelite response that directly impacted the God-idea. That response is most immediately expressed in the prophecies of First Isaiah of Jerusalem, Sennacherib's contemporary. It was the threat to the survival of Judah and Jerusalem, emanating from Assyria, which called forth an enhanced God-idea. That idea evolved into universal monotheism, and in effect, enabled the people of Israel to survive exile and domination by successive world empires. In such terms, universal monotheism is to be seen as a religious response to empire, an enduring world-view founded on the proposition that all power exercised by humans, no matter how grandiose, is transient, and ultimately subservient to a divine plan for the whole earth, for all nations.

\section{Mythic, thematic, and socio-political approaches to Israelite monotheism}

If we are to achieve greater clarity as to the true character of Israelite monotheism, it will be necessary to liberate ourselves from the dominance of certain methodologies that have held sway. One often encounters the view that the roots of monotheism go back far in human experience, to very ancient notions of a unified cosmos under the rule of a supreme, creator god. This essentially mythological approach has much to contribute to our understanding of monotheism, to be sure, but it can also be misleading. It fails to distinguish between what H. W. F. Saggs, in his monograph The Encounter with the Divine in Mesopotamia and Israel, calls the "divine in creation" and the "divine in history" (Saggs 1978: 30-92). The notion of the "cosmos as a state", to use Thorkild Jacobsen's phrase (1946, and cf. Jacobsen 1963), is a dynamic projection of human existence on earth. It expands in rhythm with the broadening of human social and political horizons - from a celestial city-state, governed by a divine council, to a kingdom of deities, to a cosmic empire. Innovations in configuring the god-idea did not originate in such mythic projections, however. They are rather a function of the "divine in history", where we find that political entities and leadership roles are projected onto or reflected in the god-idea, ultimately of a world empire ruled over by an imperial king.

In considering such developments, we must bear in mind that long periods of time elapsed until the cosmic, celestial horizon, already experienced by humans at an early period, was translated into a socio-political awareness of interconnected human societies, inhabiting far-flung regions of the known world. In fact, such a global horizon is a feature of the Neo-Assyrian period, exemplified by the many lands that are encompassed by the "Sargon Geography", a mappa mundi recently re-edited and discussed by Wayne Horowitz (1998: 67-95). The implications of its measured distances and relative locations have been discussed by Mario Liverani (2001). It was the very

\footnotetext{
* This article is the written version of the paper originally scheduled to conclude the final session of the XLIXe Rencontre Assyriologique Internationale. In the event, the report of Col. Bogdanos was much longer than expected
}

and left no time for Professor Levine to speak. It is a pleasure to right that wrong at last by publishing Professor Levine's paper here. Eds. 
expansion of the Neo-Assyrian Empire that broadened the horizon of identification of many peoples of the ancient Near East, the Israelites among them.

Here is some of what Mario Liverani has to say about imperial kingship in the context of Assyrian ideology:

A king is not legitimate because of the approval of god Aššur; a king, while he rules in Assyria is always legitimate, and his legitimacy is expressed in religious terms. In a broader sense, the divine approval is not the cause of the legitimacy of the action, it is clearly its expressed form. Therefore it would be incorrect to speak of the Assyrian king as "non-absolutist" in so far as he acts in the name and stead of the god Aššrur, since Aššur is precisely the hypostasis of the Assyrian kingship (Liverani 1979: 301).

We can say the same regarding kingship in ancient Israel, even though some biblical scholars resist comparative insights because of their theological implications. As examples, the profiles of ideal kingship set forth in Isaiah 9: 5-6 and 11:1-10, whether or not they refer in the first instance to Hezekiah, express the very hypostasis of which Liverani speaks. The attributes of the ideal king, his wise counsel and judgment, and his capacity to resolve conflicts peacefully rather than by use of military force, are said to have been endowed by the God of Israel. It would be more accurate to invert this statement: Yahweh is the ideal king, by virtue of the fact that kingship serves as the model for configuring the God-idea. Anticipating the discussion to follow, it is interesting to note that in one of the Assyrian prophecies, which Simo Parpola entitles "Prophecies for the Crown Prince Aššurbanipal", the kings of the lands come to Aššurbanipal to seek arbitration of their disputes. Parpola notes the comparison with the visions of world peace in Isaiah 2 // Micah 4 (Parpola 1997: 38, 11. 8-13).

This observation leads directly to the second methodological caveat, and to further consideration of Simo Parpola's recent studies. As is true of most students of the rise of monotheism in ancient Israel, Parpola focuses on thematic and conceptual similarities among religions, using phenomenological models, albeit with new evidence and deepened insight. He regards the ascendancy of the cult of Aššur during the Neo-Assyrian period as having had a direct bearing on the development of Israelite monotheism, an approach now further elaborated in his introduction to the volume of Assyrian prophecies (Parpola 1997: xiii-cviii). Parpola draws his evidence primarily from religious documents in configuring the god Aššur as head of the Assyrian pantheon. It is his view that Aššur came to embody all of the gods, beyond synthesizing all of their attributes, and he explores the relevance of this process for understanding the development of Israelite monotheism.

Although it is valid to conclude that Aššur eclipsed the other gods of the Assyrian pantheon as the Neo-Assyrian period progressed, it is not accurate to state that references to other gods in treaties, oaths and rituals, and in royal inscriptions and correspondence came to an end (on this, and related issues raised by Parpola's interpretation of Assyrian religion, see Porter 2000 and Weippert 2002). In a more fundamental respect, it is doubtful whether any amount of thematic or theological analysis of divine functions and attributes, however penetrating, can fully explain either the ascendancy of the god Aššr in Assyria, or of Yahweh in ancient Israel. Such analysis, as helpful as it is in describing phenomena, cannot explain why these divine "personalities", if one may use the term, emerged at specific times and locales, under particular circumstances. For this we require an understanding of the ideological dimensions of political history.

The importance of political documents as sources for the study of religion was brought home by a study of religious and legal concepts in the parity treaty between Ramesses II and Hattušili III. That study was undertaken in the mid-1990s in collaboration with my colleague at New York University, the Egyptologist Ogden Goelet (Goelet-Levine 1998). The Egyptian-Hittite treaty drew attention to political documents, especially those that speak for major ancient Near Eastern powers, as informative sources for the study of religion. It provided a clear illustration of how religious ideas, including conceptions of the gods, can be understood as responses to changing political realities. A critical edition of both versions of the treaty by Elmar Edel appeared posthumously (Edel 1997).

The treaty projects a bipolar world-order in which power is to be shared by Egypt and Hatti under their respective rulers on earth, and in heaven by the chief deity of each party, the sun-god representing Egypt and the weather-god representing the Hittites. Such two-dimensional parity pervades both the introductory section of the treaty and the paired line-up of divine witnesses to 
its enactment at the conclusion. In ideological translation, the treaty mirrored the political realities of the mid-thirteenth century BCE, pursuant to the historic impasse at the battle of Kadesh on the Orontes, where Egyptian power had been checked to a critical degree.

What is most interesting is that the treaty breaks with traditional claims of invincibility, especially prominent in the Egyptian sources, and instead of asserting that the chief god of one or the other power had guaranteed victory to his chosen king, sanctioned the resulting status quo, a détente of sorts, as having been divinely ordained from time immemorial. We encounter brotherly language reminiscent of earlier correspondence pertaining to royal marriages between Egypt and other powers, and such treaty language is subsequently cited in the Ramesside correspondence.

In religious terms, no one deity was perceived at the time as ruling over both Egypt and Hatti, just as, in reality, no one earthly empire enjoyed unrivalled power. A careful study of the Egyptian term $p 3$ ntr "the god", and its Akkadian parallel, DINGIR-li, occurring only once in the introduction to the treaty, led us to conclude that this terminology did not refer to a single, omnipotent deity, but either to some impersonal notion of divinity, or more likely, to the deity of reference, in immediate context. On this and other subjects related to the often adduced Egyptian precursors of Israelite monotheism, the reader is referred to the work by Erik Hornung (1982) on Egyptian conceptions of the divine. For its part, the Ramesside treaty captured a moment in the history of religious ideas, a message of earthly and cosmic peace, pronounced subsequent to the Amarna period, and just preceding the critical twelfth century BCE. The title of our 1998 study began: "Making Peace in Heaven and on Earth".

Studying this remarkable parity treaty left me with an afterthought that soon became an urgent question: If the Egyptian-Hittite treaty spoke for a bipolar world order, how would political documents that spoke for a unipolar world power express divine sanctions? Would they not proclaim the global supremacy of the unrivalled chief god of the imperial pantheon of the sole world-empire? With the historical context of classical, biblical prophecy in mind, I turned to the Neo-Assyrian annals and royal inscriptions of the eighth to seventh centuries BCE, from TiglathPileser III, through Sargon II, to Sennacherib and beyond. In line with earlier Assyrian traditions, such documents speak of expansive conquests, and project a world dominated by the king of Assyria on earth and by the god Aššr in heaven. During this period, the ancient mandate of the Assyrian kings to expand their territory, to tread where no previous king had been before, was achieved in large measure, persistent rebellions and challenges to Assyrian hegemony notwithstanding.

The growing pre-eminence of the god Aššur at the expense of Marduk, the venerated patron deity of Babylon, can be correlated precisely with Sennacherib's aggressive policy toward Babylonia. What is more, the Assyrian claim to world supremacy and the exaltation of Aššu were most emphatic at the very time that Jerusalem and Judah were in the greatest danger. It is fascinating to contemplate that Sennacherib, that most celebrated servant of Aššur, may have inadvertently played a major role in assuring the enduring worship of Yahweh, the God of Israel!

I hypothesized that the critical political events of the Sargonid period, and the ideology that was generated by them, would have elicited an Israelite response, which was to go beyond the situation of the moment and have a lasting effect on Israelite religion. It is better to speak of response than of influence; in truth, response may be the clearest form of influence. This observation is directly relevant, because the Hebrew Bible, which fails to provide explicit evidence of stages in the development of Israelite religion, and contains no political documents in original form, nevertheless preserves distinctive, if not unique paradigms of response literature. As regards the present discussion, such responses are associated with the role of First Isaiah in counseling Judean kings against rebellion and anti-Assyrian alliances. The prophetic counsel, expressed overtly in the historiography of II Kings 18-20// Isaiah 36-9, is encoded in those sections of Isaiah 1-39 that can be reliably identified as Isaianic, thereby requiring us to decode the prophetic message. If properly understood, Isaiah's prophecies reveal how those who spoke for a beleaguered and conquered people reacted to the overwhelming impact of Assyrian conquest, and more generally, to the persistent threats of imperial power. In these orations, among the most beautiful examples of ancient Hebrew poetry, we hear the voice of the defeated trying to make sense of their desperate 
situation. Thus, Mario Liverani once again, in his discussion of the function of the imperialist ideology in times of conquest:

At the moment of the impact there obviously takes place a struggle between ideologies; each providing its own audience with the explanation of what is happening: as there is an ideological justification for the victory, there can be an ideological justification for defeat and subjugation. When we possess sources from conquered countries, as in the case of Israel, the comparison is possible and rather enlightening (Liverani 1979: 300).

We have clear indications that biblical authors of the period, foremost among them First Isaiah, not only knew what the Sargonid kings were about, but were also familiar with the particular style and idiom of Neo-Assyrian documents of the period. That they were clearly informed of Neo-Assyrian ideology, or propaganda, if you wish, is further indicated by their efforts to skew it to their own purposes. Thus, Peter Machinist (1983) identifies a series of specific idioms and motifs common to First Isaiah and the Neo-Assyrian sources, drawing many of his examples from the annals of Sargon II. In an ideological mode, Mordechai Cogan (1974: 9-15) focuses on motifs such as divine abandonment, which figure in both biblical and Assyrian rationalizations of defeat, both of one's own forces and of those of the enemy. John Brinkman (1983) greatly clarifies this phenomenon by analysing Esarhaddon's reflections on the causes of Babylon's downfall. In biblical prophecy, these rationalizations were enhanced, supplying causes for the displeasure of the God of Israel. Attributions of culpability ranged from religious to social and moral offenses, from idolatry to injustice and corruption, from religious hypocrisy to mistreatment of the poor and weak.

Thus far, I have published a preliminary Hebrew study on this subject (Levine 2003). A further elaboration of it in German, translated from lectures I delivered at several German universities in October 2001, has also appeared in a collection of studies on the subject of monotheism, entitled Der eine Gott und die Götter (Levine 2003a). This is my third effort, in which there will be inevitable repetition, but also a new emphasis on the cult of Aššur.

As already stated, it is my contention that in the Judean society of First Isaiah's time, the immediacy and inescapable force of the Assyrian threat demanded a God-idea broad enough to measure up to empire. First Isaiah expounded just such a concept for the first time in biblical literature. He preached that international events, albeit catastrophic, were going according to the plan of the God of Israel for the whole earth. Powerful Assyria, with its boastful king, was nothing more than an instrument of punishment, a rod of rage wielded by the God of Israel against his own people.

The sparing of Jerusalem from destruction by Sennacherib in $701 \mathrm{BCE}$, regarded in Hebrew Scripture as miraculous, served as a powerful sign that the God of Israel controlled the fortunes of the Assyrians. Remember the refrain of the Assyrian royal annals: $i-n a$ e-muq ${ }^{\mathrm{d}} A \check{s}$-šsur EN-ia "By the strength of Aššur, my lord" (Frahm 1994: 51, 1.9 et passim). If it is Aššur who empowers the Assyrian empire, only a Yahweh more powerful still could rescue even a remnant of Israel.

\section{From henotheism to monotheism: The expanding horizon of Israelite religion}

Before attempting to interpret First Isaiah's conception of God, it would be well to step back for a moment, and to ask how religious thinking in Jerusalem and Judah arrived at this point of development. We have already identified several methodologies, indicating that it is the sociopolitical approach that affords the clearest insights into the development of Israelite monotheism, because the most appropriate model for configuring universal monotheism is world-empire. If it is accurate to say that concepts of the divine expand in response to an expanding horizon of identification, we can identify at least two overlapping phases in the expanding Israelite horizon, the regional and the global. A disproportionate amount of attention has been devoted to the former, and too little to the latter!

The regional phase, which began earlier and overlapped with the global, is associated with the emergence of the Israelite societies and the founding of two monarchies in Canaan. It involves confrontations with Canaanites and Philistines, and with neighboring peoples - Ammonites, Moabites, Edomites and Midianites. I would include encounters with the expanding Aramean kingdom in Syria and the less bellicose Phoenician city states. All of these entities shared an overarching West Semitic pantheon, known in earlier forms from Ugaritic myth and ritual, where El 
and the younger Baal, and Ashtoret and Asherah, and Dagon, and some other divinities, realized in various manifestations, held sway. At the same time, we note the presence of national gods Kemosh of the Moabites, for instance, and Yahweh of the Israelites.

The "central concern" (once again, a locution favored by Thorkild Jacobsen) of the Yahwistic leadership in this context was to demonstrate that it was Yahweh, the tribal-national god of the Israelites, not some other deity, such as El or Baal, who had granted his people sovereignty in Canaan and victory over neighboring foes. The religious agenda was directed at advancing henotheistic Yahwism. The Israelites are told in Exodus 6 that El, who was worshipped by their patriarchs, is only a manifestation of Yahweh: Yahweh by another name. It was really Yahweh who brought them out of Egypt.

The Egyptian saga, which projects a war of gods between Yahweh and the mighty gods of Egypt, is part of the henotheistic phase. Some would dispute this classification because, as a world power, Egypt was a recurring variable in relations between Northern Israel and Judah, and the Mesopotamian empires. However, the saga of liberation from Egyptian bondage more properly belongs with the conquest-settlement traditions, and is very different in tone from the chronicles of II Kings, and from prophetic reactions to the Neo-Assyrian threat, as will become evident in the discussion to follow. The Egyptian saga served to inform Israelites, in a manner perhaps more epic than historical, how they came to live in Canaan in the first place.

The national agenda is epitomized in the narratives of the book of Judges, which may have been composed as far back as the eighth or ninth century BCE. Thus, Gideon is reassured that Yahweh, not Baal and his Asherah, will bring him victory over the Midianites (Judges 6). We are told that Gideon had heard of Yahweh and his wondrous deeds at the Exodus, but had yet to be persuaded that Yahweh was with him in his current battles. Similarly, in Judges 11 we find Jephthah telling the Ammonites that what Kemosh (apparently on loan from the Moabites) had granted them is theirs, but what Yahweh had granted Israel is theirs. In seeking to explain how exclusive Yahwism ultimately predominated in Judah in the near-exilic period, the best I can come up with is this: The fervor of the national movement led to the progressive paring-away of gods and goddesses, and the exaltation of the national God, Yahweh (Levine 1996).

In the same polemical spirit, Elijah at the Muhraqa of the Carmel range demands that the people, living in an area of mixed Phoenician and Israelite demography, choose between Baal and Yahweh (I Kings 18): That message is conveyed in tales that condemn the policy of the Northern Israelite king, Ahab, of the ninth century BCE. If we want to know why El was synthesized and Baal rejected by the same Yahwists, we shall not find the answer in the respective attributes of these two deities. As we now know from Ugaritic mythology, both were beneficent heaven gods. The answer lies in the fact that Baal worship presented a real and present threat to the spread of Yahwism early on, especially in the Northern Kingdom, whereas El worship apparently did not. In fact, the only early polemic against El worship, as manifested in the bull cult, is to found in some veiled references in Hosea $(8: 4-5,10: 5)$ to heterodox practices among the Transjordanian Israelites of Gilead.

It must be conceded that there are certain aspects of the rejection of polytheism, evident in early Israelite religion, which I am at a loss to explain fully. It seems that we are confronted by a culture that we do not fully understand, a mentality that was averse to goddesses and emphatically aniconic. Trygve Mettinger (1979), Saul Olyan (1988), Morton Smith (1971), and Mark Smith (1991, 2001) have further clarified these aspects of religious life in ancient Israel. More recently, there is the study by Bernhard Lang (2003), entitled "Die Jahwe-allein-Bewegung", which takes its cue from the label coined by Morton Smith, "The Yahweh-Alone" party. For his part, Olyan deals with the cult of Asherah, and Mettinger discusses current views on iconography and the ban on cult images. Morton Smith has attempted to chart the internal tension between the strict Yahwists and those endorsing a more traditional and less exclusive cultic policy. Mark Smith has contributed a regional overview, with strong emphasis on the Ugaritic sources. In sum, although we now possess a greater understanding of what happened in ancient Israel, and how it happened, we still cannot fully explain why religious thinking took the course that it did.

Perhaps we can achieve greater clarity about why the global horizon emerged in ancient Israel when it did. It begins to be felt when the security of Judah and Northern Israel became increasingly 
affected by the western campaigns of the Assyrian Empire, situated as these kingdoms were in the crosscurrent with Egypt. We see early signs of this expanded horizon in the prophecies of Hosea and Amos. Yahwistic henotheism was fast becoming untenable, as the Neo-Assyrian threat produced a crisis of faith, along with more practical dangers. The global horizon reaches its apex in First Isaiah, who talks most noticeably about Israel's fate and the destiny of empires. In a sense, that conversation was to continue indefinitely throughout Jewish history, as the people of Israel, inside its land and outside of it, lived under successive imperial regimes - Babylonian, Persian, Seleucid, Roman, and so on. It was not too long until prophecy, an historically oriented genre, gave way to apocalyptic, which spoke of the end of history and a new world to come.

It is my sense that the most significant breakthrough in the development of Israelite monotheism was not the exclusionary break-away of Israelite henotheism from its counterparts in the region, but rather its vital response to Assyrian imperialism. The exclusive worship of Yahweh, the Israelite national God, though surely basic to Israelite monotheism, represents only one phase in the process. Monotheism became universal only at the point when Yahweh was declared to be the sole sovereign over all nations. In this respect, the statement of the Decalogue, "You shall have no other gods (אלהים אחרים) in my presence", is best taken as henotheistic, not strictly as monotheistic, as it has been understood in both the Jewish and Christian traditions.

\section{Assyria and Judah: The historical background}

The historical review could begin at any one of several points during the Sargonid period, but the most critical time to be examined for present purposes is the reign of Sennacherib (705-681), viewed against the background of Sargon II, his predecessor. Mario Liverani and Hayim Tadmor, foremost among many, have not only clarified the events of this period but have developed methodologies for dealing with the ideological underpinnings of Assyrian imperialism. John Brinkman has contributed a penetrating treatment of the view from Babylonia. Coming to this area of inquiry from biblical and West Semitic studies, I have drawn extensively on the findings of these and other scholars. For purposes of the present discussion, a general historical outline of the immediate situation in Judah prior to the Assyrian blockade of Jerusalem in 701 will suffice.

During the first years of his reign, which began in 705 after the death of Sargon II in battle in Cilicia, Sennacherib embarked on major campaigns, first to Babylonia and then to Judah and the west, after rebellions had broken out in both quarters. Merodach-Baladan II, a veteran fomenter of insurrections in Babylonia, was in contact with Hezekiah, king of Judah in Jerusalem, so that we have at the very least, a triangulated situation if not an outright alliance (Brinkman 1964, 1973, 1984: 45-83). The Egyptian forces that came to Hezekiah's aid were defeated, and Sennacherib's army arrived at the gates of Jerusalem in 701, after the Assyrian capture of Lachish. According to both the annals of Sennacherib's third campaign and the biblical account in II Kings, notwithstanding their differences, Sennacherib did not destroy Jerusalem or annex Judah. After devastating the area, he accepted heavy tribute from Hezekiah. Some biblical scholars and political historians, including A. Kirk Grayson (1992), have considered it probable that there was a second Assyrian campaign against Judah later in Sennacherib's reign, after his destruction of Babylon in 689. It was then, according to this view, that the Nubian Pharaoh, Tarhaqa, led an army into Palestine (II Kings 19: 9-13). There is no Assyrian evidence for a second campaign, and it is likely that such a reconstruction of events is harmonistic, and not historical.

As for Sennacherib, he took his time in solving the Babylonian problem to his satisfaction (although it did not remain solved!), and after successive campaigns and changes in Babylonian administration, he destroyed the city and its temples, foremost among them Esagila in 689 (Brinkman 1973). He was murdered by one of his sons in Nineveh in 681, an event that did not go unnoticed in the Hebrew Bible. Note the typological telescoping of events in II Kings 19: 36-7. In v. 36 we are told that Sennacherib returned to Nineveh, an event that presumably occurred ca 701, and in the very next verse we read that he was murdered, an event that we know occurred twenty years later. In the mind of the biblical historiographer, divine justice was on fast-forward!

Throughout the better part of the second half of the eighth century BCE, Isaiah had counseled against rebellion and anti-Assyrian alliances. The so-called "Syro-Ephraimite" coalition against Assyria had led to the annexation of the Northern Kingdom and the deportation of much of its 
population (Cazelles 1992). However we frame the events of the period between the fall of Samaria and the death of Sargon, from ca 720 to 705, involving Hezekiah either more or less in antiAssyrian activity, it is clear that after Sargon's death in 705 Hezekiah committed the serious error of going against the prophet's counsel. He ceased to pay tribute, and in an effort to exercise hegemony in the south, deposed the Philistine ruler of Ekron, Padi (Na'aman 1994). The name Padi has now been attested in a royal dedicatory inscription from Tell Miqneh-Ekron (Gitin et al. 1997).

Tadmor (1986) goes into considerable detail to emphasize the international scope of the political and military situation at the unusual death of Sargon II, the first king in Assyrian history to die in battle, whose body was never retrieved, and who was left unburied. These events undoubtedly sent shock-waves throughout the empire, and the fact that Sennacherib waited four years before launching his campaign to Judah and the west suggests hesitation on his part about undertaking this venture at all. It may not have been entirely unreasonable for Hezekiah and others in the west, far from the Assyrian heartland, to calculate that rebellion would succeed. Hezekiah's final decision to submit to the Assyrian yoke saved the day, and if we accept the basic record of events as presented by the authors and redactors of II Kings 18-20//Isaiah 36-9, that decision was obedient to First Isaiah's counsel. Jerusalem was spared, which was a powerful sign of divine providence.

The end-result of Sennacherib's military ventures in Judah was unexpected, for it was not Assyrian policy to leave the capital of an insurrectionist kingdom standing on its tell. There have been diverse explanations as to why Sennacherib spared Jerusalem, none of them conclusive. Eva von Dassow (by written communication) speculates that Padi, the Philistine ruler of Ekron, may have served as Hezekiah's bargaining chip. Sennacherib may have been content to restore his own hegemony in Philistia by securing Padi's release and reinstatement, to collect tribute, and to leave a submissive Hezekiah in Jerusalem. In any event, both Hezekiah and Jerusalem survived!

The Book of Kings presents a highly unfavorable view of the long reign of Manasseh that is conditioned by a particular religious outlook, focusing on his heterodoxy. He was in reality an effective king under the precarious circumstances. Israel Finkelstein (1994) has summarized in considerable detail the sketchy archeological record of the seventh century BCE prior to the reign of Josiah, and concludes that under Manasseh the kingdom of Judah continued to exist, albeit with a seriously reduced population and the loss of the fertile Shephelah. Nevertheless, Jerusalem remained the capital of Judah throughout the seventh century, though its area and population density during the middle part of the century are not known for certain. Manasseh continued to pay tribute to the Assyrians, but perhaps not as much as was formerly thought. Actually, Judah began an economic revival, attributable in large measure to activity in the Beer-Sheba area on the Arabian trade routes. Finkelstein suggests that this effort was actively encouraged by the Assyrians for their own purposes. There is reference to Manasseh's construction projects in II Chron 33: 14, which may preserve historical information.

In retrospect, it is sobering to realize that had Jerusalem not been spared in 701, Judah would have undoubtedly met the same fate as Northern Israel twenty years earlier, and that would have marked the end of the Israelites as a people. Even in the midst of loss, many Judeans may have been heartened by Isaiah's assurances of survival.

\section{Assyrian ideology}

In his recent essay "World Dominion: The Expanding Horizon of the Assyrian Empire", Hayim Tadmor (1999) takes us back to the reign of Tukulti-Ninurta I (1244-1208). An annual royal ritual, edited by K. F. Müller (1937), reports that the priest of Aššrur placed a scepter in the hand of the king and commanded him, "With your just scepter, extend your land!" Assyrian kings also received weapons with which to carry out this mandate. Curiously, I discussed the very same ritual about thirty years ago in my early studies of the biblical priestly cult, explaining the Hebrew term šelämîm as a cognate of Akkadian šulmānu, an Assyrian temple offering which figured prominently in the Assyrian royal ritual (Levine 1974: 29-32). Now my interest in this text lies not in ritual itself, but in the nexus of cult and kingship.

Tadmor immediately shifts forward in time to about six hundred years later, when a similar expansionist command is issued to Aššurbanipal. Tadmor proceeds to discuss the notion of "heroic 
priority", the duty of a king to tread where none of his predecessors had ventured, to extend the land of Aššr. We thus observe an ideological continuity, beginning even before Tukulti-Ninurta I and reaching down to the last Assyrian kings of the seventh century BCE, endorsing military expansion and exalting the god Aššr as its divine standard bearer. The claim that history repeats itself has no better demonstration than that provided by a comparison of the reigns of TukultiNinurta I and Sennacherib. Both Machinist (1976), in his study of the Tukulti-Ninurta epic, and Tadmor take particular note of the seal from Babylon mentioned in one of Sennacherib's inscriptions. It had been seized as booty by Tukulti-Ninurta I and somehow found its way back to Babylon, only to be retrieved once again by Sennacherib from the spoils of Babylon. The obverse of the inscription reads in part, "I, Sennacherib, King of Assyria, after six hundred years, conquered Babylon, and from the wealth of Babylon, I retrieved it" (Luckenbill 1924: 93, d 11. 5-7). This recollection is a fascinating example of how memory functions in historical writing, as traditional justification. It also directs our attention to an important cultic-political correlation between (a) Sennacherib's Babylonian policy, which marked a departure from that of Sargon II, and from almost all of his predecessors, and (b) the consequent rise in status of Aššr at the expense of Marduk, the venerated patron deity of Babylon, as will be discussed presently.

In retrospect, as Tadmor explains, Sennacherib did not excel at "heroic priority", as had TiglathPileser III and Sargon II. He inherited an empire rather than creating one through expansion, and his third campaign to Judah and the west was actually exceptional. Sennacherib rather focused on the center, on subduing Babylonia and having Assyria take its place as the heart of empire. Tadmor (1989) explains how the militant policy of Sennacherib toward Babylonia was registered and expressed in texts related to the cult of Aššr, and in epic and royal inscriptions, all of which signaled changes in Assyrian religion. A valuable treatment of texts relevant to what is often termed the theological reform of Sennacherib is provided in concise form, with critical analysis, by Eckart Frahm in his recent work, Einleitung in die Sanherib-Inschriften-(1997: 220-9), under the headings "Reformtheologisch inspirierte Texte mit Bezug zum Gott Aššur" and "Die "Sünde Sargons' und ein verwandter Text". These sections are followed by a thematic discussion entitled "Exkurs: Die Inschriften als Quellen für Sanheribs Religionspolitik" (Frahm 1997: 282-8), where Frahm speaks of the "'Persönlichkeit' Aššurs".

Beginning in the reign of Sargon II we find, in texts coming mainly from the old Assyrian capital of Aššur, the name of the god Aššur written as AN.ŠÁR. Tadmor has analysed in depth the significant import of this spelling, in several of his studies. AN.ŠÁR is the name of a Babylonian cosmogonic deity, and this rendering of the name of Aššur identifies AN.Šár with the similarly sounding Assyrian god. Initially, this identification might have served the pro-Babylonian Sargon II in making the god Aššur more acceptably "Babylonian", but later, in the reign of Sennacherib, it served to indicate that Aššur-AN.ŠÁR, not Marduk, ruled Babylon, just as Assyria ruled in reality. Significantly, the writing AN.ŠÁR is found in this period only at in the city of Ǎšsur, whereas in texts from Nineveh the traditional writing is used. Added to this is the titulary of Sennacherib from Aššr, naming this king as the one who fashioned the statue of AN.ŠÁR (see further below). This important cultic event can be dated to the period between 704 and 700 . After the destruction of Babylon in 689, additional symbolic acts reinforced the demotion of Marduk: The titulary of Aššur becomes grander, and the bīt akitti ša șerri at Aššur is renovated and dedicated to AššurAN.Š́́R. Dust from the destroyed Babylon is placed there, and additional accoutrements are shipped to Aššur from Babylon. It is the god Aššur who vanquishes Tiamat in the Assyrian version of Enuma Eliš, not Marduk, and Sennacherib rides together with the god Aššur in his divine chariot!

Another way of assessing change is to study the enhancement of the god Aššr's epithets, if we may call them that, in tandem with the variants in the titulary of Sennacherib. We are fortunate in having a study of Sennacherib's titulary by Mario Liverani (1981), who contrasts the developing Nineveh versions with the static Aššur version. The Aššur version, from the final years of Sennacherib's reign, is focused on the king's building projects and related activities honoring the gods, especially Aššur, whereas the Nineveh version "morphs", and becomes grander in rhythm with his heroic campaigns and conquests during his reign. The result of this analysis yields a long list of status indicators, which can be classified in various ways. Sennacherib is empowered by 
Aššr, head of the gods, who granted him unrivalled kingship and invincible weapons, and caused powerful princes to fear his military advance. He has dominion over vast territories, over the four quarters, from the upper sea to the lower sea, and can traverse the earth with no interference. All of the black-headed men fall at his feet in submission. We also encounter epithets than express royal virtues - love of justice, what Liverani calls "pietistic pastoral titles", qualities that enhanced the king's favor in the sight of the gods.

As for the god Aššur, we can further pinpoint his divine "personality", and Sennacherib's special relationship to him, by reference to the Tablet of Destinies (tuppi šimāti), Text B, in the British Museum, a fascinating text interpreted by Andrew George (1986), and based on a join made by Wilfred Lambert. It depicts Sennacherib as the cultically devoted king who did so much to honor Aššur, and who humbles himself before him, praying to him for further blessings, most of all for the continuation of his dynasty: $\left.i \check{s} i d{ }^{\text {gi }}{ }^{\check{5}} k\right]$ ussi-ia kima šadí $l i-k u n$ a-na $u_{4}-m i r[e-q u-t i]$ "Let the base of my throne be secure as a mountain for long days to come" (1.20).

But more than this, the tablet assigns unusual status to the god Aššr himself, making him, not Marduk, the deity who holds in his hand the Tablet of Destinies. Aššur's image was most likely depicted on a seal imprinted on the tablet. It should be mentioned, however, that already in the final years of Sennacherib's reign we observe a conciliatory attitude toward Babylonia and Marduk, which prevails during the reign of Esarhadon, when the window of about twenty years into Aššur's exaltation over Marduk closes.

\section{First Isaiah and monotheism}

In the discussion to follow, many biblical passages, some of them quite extensive, will be presented in adapted translations, informed by the New Jewish Translation, TANAKH (1985), and for Isaiah 1-39, specifically, by the renderings of G. B. Gray (1912). How a biblical verse or passage is translated impacts our understanding of the larger issues. With due respect, I have found no single translation that is fully acceptable in every case, and have adopted the practice of introducing my own translations of cited biblical texts, and even of extra-biblical sources where deemed necessary.

Before treating selected passages from First Isaiah on the subject of monotheism, it would clarify matters if we prefaced some comment on the status of the pertinent historiographic passages in II Kings 18-20//Isaiah 36-9. Those texts are composite, and show signs of later authorship and, at points, of redaction by the Deuteronomist. Nevertheless, they have been impacted by the prophetic ideology, whether or not they are directly dependent on First Isaiah's prophecies, and at points resonate clearly with the diction of the Neo-Assyrian sources. Thus, Chaim Cohen (1979) has analysed what he refers to as "Neo-Assyrian elements" in the first Rabshaqeh speech. Although these biblical sources provide information valuable for reconstructing the events of 701 BCE, they do not have the same historical valence as do prophecies that can be reliably attributed to First Isaiah. Thus it is that poetry often sheds more light on history than chronicles do!

This said, it remains difficult, nonetheless, to assign precise dates to those texts within the canon of Isaiah 1-39 that are regarded by most biblical scholars as the genuine writings of First Isaiah. The prophecies are not arranged in chronological sequence, and the captions, where we have them, are not necessarily reliable. In a recent study entitled "Historical Information in Isaiah 1-39", Anton Schoors (1979) guides us through a frustrating maze of theories on the composition of every part of Isaiah 1-39. I must emphasize, however, that my hypothesis that First Isaiah was responding to Assyrian claims of supremacy of an ideological nature can be validated in a general way at various times during the reigns of Tiglath-Pileser III, Sargon II and Sennacherib. It is just that the early years of Sennacherib are especially focused, and ideologically magnetic, and it would be preferable to find a more precise historical location for First Isaiah's principal response, if possible. For example, it is likely that Isaiah 1 was composed soon after 701, not earlier than that. The give-away comes in vv. 8-9:

The daughter of Zion remains as a hut in a vineyard,

As a lean-to in a cucumber patch, as a besieged town.

Had not Yahweh of Hosts left us the sparsest remnant,

We would have become like Sodom,

We would have resembled Gomorrah! 
The accompanying description of conditions in Judah that is conveyed in Isaiah 1 surely fits the aftermath of Sennacherib's invasion. The whole land is devastated, towns have gone up in flames, and the populace is wounded beyond healing. The point of Isaiah's tirade against Jerusalem is that even after being rescued from mighty Assyria, and in the face of so much suffering, Jerusalem and its officialdom remain corrupt, and ironically deserve to be compared to Sodom and Gomorrah! Jerusalem can only regain its eminence through repentance and the formation of a just society, not through profuse temple worship alone. Isaiah 1 condemns the failure of Jerusalem's leaders and its society to heed Yahweh's teachings, and regards their inability to see the meaning of recent events as extreme stupidity. All of their suffering had come upon them to start with because they had abandoned the Holy One of Israel, in whom they should have trusted. They should have heeded the counsel of the prophet Isaiah who spoke in the name of the God of Israel; now they have another chance.

The monotheistic message of First Isaiah is most clearly expressed in two texts that can also be dated to the period immediately following 701, namely Isaiah 10: 5-19 and 14: 24-7. The translations will be followed by brief commentary, leaving purely textual problems to be addressed in the footnotes.

\section{1) Isaiah 10:5-15. Assyria is a punitive instrument of Yahweh's anger.}

5. "Ah, Assyria, rod of my rage!

He is an arm-staff of my wrath. ${ }^{1}$

6. I drive him against an ungodly nation,

I command him against a people who provoke me.

To take spoils and seize booty,

And to subject it to trampling, like the mire of the streets.

7. But he does not perceive it thus, nor does his mind so comprehend;

For it is in his heart to destroy, to terminate nations, more than a few!"

8. For he thinks:

"After all, my captains are all (former) kings!

9. Was Calno any different from Carchemish? ${ }^{2}$

Or Hamath fom Arpad, or Samaria from Damascus?

10. Just as my power overtook the idolatrous kingdoms, (and their images exceeded those of Jerusalem and Samaria!)

11. Verily, just as I did to Samaria and her idols, So will I do to Jerusalem and her images".

12. But when my Lord has carried out his program on Mount Zion and in Jerusalem, he will (then) visit punishment upon the fruits of the king of Assyria's pride, and on his colossal arrogance.

13. For he thought:

"By the might of my (own) arm have I done it;

And by my skill, for I am discerning.

I removed the boundaries of peoples;

I beat down their rulers, and led vast populations into exile. ${ }^{3}$

\footnotetext{
${ }^{1}$ The Masoretic text presents difficulties. ומטה הוא בידם ז', literally: "It is a staff in their arm, my wrath". This would mean that Yahweh's wrath was a staff in the arm of Assyria, which differs from what was said in the first stiche. This is, after all, an important statement, and we would מבט אכי " "rod of my rage"// מטה זעמי "staff of my wrath". What, then, is to be made of the unusual syntax, with intervening "בידם "in their arm"? Conceivably, the final mem is enclitic: ביד-מ, and not a pronominal suffix, so that the parallel of שבט was intended to be staff". The staff is wielded by extending one's arm (Exodus 7: 19, 8: 13). Emphatic "הוא "he/it is" merely breaks the construct formation. This would yield, literally: "And a
}

staff-in-arm/arm staff, he (= Assyria) is, of my wrath".

${ }^{2}$ On the toponym כלני, כלנה in Amos 6: 2 written, see Tadmor (1994: 58, comment on 11'), where information is provided on the toponym Kinalia, occurring in the inscriptions of Tiglath-Pileser III, and earlier written Kunulua, the capital of Unqi (Tell Tainat). It has been identified by J. D. Hawkins and Nadav Na'aman with Kullani, conquered by Tiglath-Pileser III in 738. The metathesis: KNL > KLN resulted from the transcription of the Neo-Hittite place name into Semitic. Nonetheless, Tadmor reports the occurrence of the form כנלה in an Aramaic inscription from Tell Tainat.

${ }^{3}$ In the history of exegesis, Hebrew ועתודיהם (Qere; ועתידיהם Kethib) has been taken in several ways. The most frequent rendering is "their treasures, stores". The 
14. I was able to seize, as (from) a nest, the wealth of peoples;

And just as one gathers abandoned eggs,

So did I rein in the whole earth.

And no one so much as flapped a wing, or opened a mouth to chirp!"

15. Should the axe boast over the one who hews with it?

Should the saw lord it over the one wielding it?

As though the rod can wave the one who raises it;

As though a staff can lift (a man) not of wood!

16. Therefore, the Sovereign, Yahweh of Hosts,

Will drive leanness into his corpulence,

So that under his great body there shall be a burning like that of fire,

$\langle 18 \mathrm{~b}-\mathrm{c}$ : Destroying frame and flesh, until he wastes away,

Like one deteriorating from illness, $>$

17. The Light of Israel shall be (that) fire, and his Holy One (that) flame.

It shall burn and consume his thorns and his thistles in a single day;

<18a. Along with the great mass of his scrub, and his garden land. $>$

19. And the trees that remain of his scrub shall be so few in number,

So that a mere youth would know how to record them!

Commentary. Isaiah 10: 5-19 has received extensive attention from biblical commentators, many of whom question the integrity of this prophecy. It is not my intention to discuss its composition here because, aside from the juxtaposition of part of v. 18 indicated in the translation, I see no reason not to treat it as an organic whole. The first part of the prophecy (vv. 5-11) clearly postdates $721 \mathrm{BCE}$, because, in his boasting, the unnamed king of Assyria refers explicitly to the capture of Samaria (v. 11). The question is, by how many years? It is probable that in listing conquered capitals in the west, this prophecy is telescoping the exploits of several Assyrian kings, beginning with Tiglath-Pileser III, continuing with Sargon II, and concluding with Sennacherib, who would be the king most likely to have threatened Jerusalem. The closest we come to this tone of voice is in Amos 6: 2, within an earlier prophecy on the fall of Samaria, capital of Northern Israel:

Traverse Calneh and observe,

Proceed from there to Greater Hamath,

Then descend to Gath of the Philistines.

Are (you) better than those kingdoms;

Is your territory larger than theirs?

There is, therefore, a typology of boastfulness in prophetic literature, and it continues through Isaiah 10: 13-15, where the Assyrian conqueror boasts of altering boundaries, deporting populations, and reining in the whole earth, acquiring its wealth like one gathering abandoned eggs from a nest. All of this reminds us of the Neo-Assyrian annals, as noted by any number of scholars. The prophecy concludes in Isaiah 10: 16-19 with a prediction of Assyria's downfall, the punishment for the hubris of its kings, and the retribution for its cruel history of oppression. Like Isaiah 1, such a prediction would have enjoyed very little credibility in the years preceding the Assyrian blockade of 701 by Sennacherib's forces, but it might have had dramatic impact after the sparing of Jerusalem, which was a powerful sign of divine providence.

conqueror plunders or destroys what has been laid away for the future. This is a forced rendering, because the root ' $-t-d$ means "to stand, be ready", and in certain Aramaic dialects the Pael, with causative force, means "to erect, prepare, make ready" (Hoftijzer-Jongeling 1995: 897 s.v. ${ }^{~} t d_{1}$ ). This is how certain forms of this root appropriated the sense of "future" (cf. Deut 32: 35, Esther 3: 14, 8: 13). Some, including the Medieval Jewish commentary Isaiah of Trani (Cohen 1996: 83 s.v. Isa 10: 13), have taken this locution to mean "chieftains", those who stand at the head of the flock, citing Isaiah 14: 9, where צתודי ארץ "the chieftains of the earth" is parallel with מלכי "the kings of the nations".
Hebrew עתוד means "mature he-goat, ram" (Gen 31: 10, 12), so-called because he "mounts" females in mating. In the biblical mentality, leadership roles are often expressed figuratively, having been appropriated from the pastoral economy. The overall sense of the verse is that the conqueror removes boundaries, subdues leaders, and exiles large populations (literally: "inhabitants"). A third possibility is that the Hebrew is to be rendered "their fortifications", a connotation suggested by the meaning "to stand". It is often said of Assyrian conquerors that they lay waste to towns and fortifications. The orthography of Hebrew unusual, but the meaning is clear: "many, multitude". 
Isaiah's doctrine is that the People of Israel are being punished by their God at the hand of Assyria. This is, at the heart of it, a traditional Israelite ideology for explaining defeat. We know, of course, that it is not at all limited to biblical writers. It has been shown that Assyrian ideologists at times placed the blame for the defeat of their enemies on the enemies themselves, and we encounter in the Assyrian sources what has been called the "motif of abandonment", whereby patron deities abandon their own sacred cities, as Marduk was said to have abandoned Babylon (Cogan 1974: 9-15, Tadmor 1986). Closer to home, Mesha, king of Moab in the mid-ninth century BCE similarly explains his loss of territory to Northern Israel as the punishment imposed by Kemosh. The national god of the Moabites had become enraged at his own land, handing it over to the enemy, in that case, Northern Israel (Dearman-Mattingly 1992).

What makes Isaiah 10:5-19 so remarkable within biblical literature is its global horizon. We read that Yahweh, the national God of Israel, a small and powerless people, is using Assyria, the global empire, as a punitive tool against his own people. In effect, the Israelite response has risen to the dimensions of the triumphal claims of the Assyrians. Yahweh controls the Assyrian Empire, and it is he who has granted the kings of Assyria their many victories and conquests. In my sequencing of the biblical sources, First Isaiah is the first to state the matter in such terms. None of the early narratives, neither the Yahwist or the Elohist of Torah literature, looks at history this way, and none of the other eighth-century prophets went as far as Isaiah in articulating this global perspective. It is only later that we find resonance of this ideology, as in Deuteronomy 4, especially v. 35: "It has been clearly demonstrated to you that Yahweh, he is the (true) God; there is no other besides him".

Now, Isaiah does not mention the god Aššur, or any other Assyrian god for that matter. Isaiah employs the Hebrew אשור, which refers to the unnamed king of Assyria (explicitly מלך אשור in Isaiah 10:12a, and in 7:17, 8: 4 etc.) and to Assyria, the land and/or its people, and the empire. Conceivably, the triad - (a) Aššur the city, (b) Aššur the land and empire, (c) Aššur the god might allow us to detect in Isaiah's exclamation, הוי אשור "Ah, Assyria", a veiled allusion to the deity with that name. However, Isaiah would not openly acknowledge the existence, much less the power of the head of the Assyrian pantheon! He does not project a battle of gods between Yahweh and Ašsur, as the authors of the Egyptian saga do between Yahweh and the gods of Egypt. Yahweh is not Aššur's adversary or counterpart, he is the only true God. For First Isaiah there were no "other gods", to cite the Decalogue, only idols, and omens and magic. In Isaiah 8: 19-21 Isaiah mocks those who have recourse to various forms of divination, making oracular inquiry of their dead would-be gods on behalf of the living. Granted, in Isaiah 14 the unnamed king of the $m \bar{a} \breve{s} \bar{a} l$ (most probably Sargon II) is said to have pretensions of celestial exaltation, of dwelling at the side of El with the West Semitic pantheon atop Mt Zaphon. But that is just more of the same hubris that we observe in Isaiah 10, put into the mouth of a foreign king. For Isaiah, it is all the king of Assyria's doing, in accordance with Yahweh's plan. He is an instrument of Yahweh, carrying out his commands.

In the Assyrian inscriptions, kings not only boast of their own conquests, as Isaiah accuses them of doing, but, as we would expect, dutifully credit their gods with their victories. In Assyrian eyes, this recognition of divine power on the part of their kings may have made their boasts more acceptable. But Isaiah cannot see things this way. Rather, he rationalizes the eventual downfall of the Assyrian king by seeing it as a consequence of his hubris, in the same spirit that Israelite kings are warned against boastfulness in Deuteronomy 17, the so-called "law of the king". The boasting of the Assyrian king forces the hand of Yahweh, who is sovereign over all nations, to intervene on Israel's behalf, because Yahweh will never countenance such arrogation of power. Come to think of it, the bias evident in Isaiah's taunt actually points to an important feature of response literature: Those who respond internalize; they factor-in their own ideological culture, at times inverting the propaganda of the other.

2) Isaiah 14:24-7. Yahweh takes an oath that he will destroy Assyria and release Judah from its yoke. Yahweh of Hosts has taken an oath, saying:

As I have devised, so has it happened;

As I have planned, so has it come about. 
To break Assyria in my land;

To trample him on my mountains.

His yoke shall be removed from him,

And his tributary burden removed from their back.

This is the plan (העצה) devised for all the earth,

And this is the arm outstretched over all the nations.

For Yahweh of the heavenly hosts had devised it, who can foil it?

And his outstretched arm - who can stay it?

Commentary. This brief passage is an explicit statement of Isaiah's monotheism. It was undoubtedly composed soon after 701, for the same reasons already adduced with respect to Isaiah 1 and 10: 5-19. Reference to an oath taken by Yahweh, God of Israel, is highly suggestive against the background of Neo-Asssyrian loyalty oaths imposed on vassals (Tadmor 1982). It parallels the divine sanctions characteristic of treaties, according to which the gods guarantee protection to those who fulfill their treaty obligations. Another tell-tale resonance is the reference to the yoke of Assyria and to payment of tribute. In his annals, Sennacherib states that Hezekiah did not submit to his yoke, for which he was severely penalized by the imposition of heavy tribute (mandattu; Luckenbill 1924: 32-4, 11. 18-49; Frahm 1997: 54-5, 11. 49-58).

Of course, things did not turn out as well as promised; the Assyrian yoke was not removed from Judah during the reign of Manasseh. And yet, the improbable turn of events by which Jerusalem survived the Assyrian threat surely lent credence to Isaiah's assurance that Yahweh controlled the destiny of Assyria, and that matters had been going according to his plan for all the earth. First Isaiah introduces a grand idea that came to dominate religious thought in ancient Israel, although it was often resisted. The God of Israel rules over empires and their kings and determines their fate according to his plan for all the earth. He commands his people Israel to submit to his designated imperial agents. Because Hezekiah heeded Isaiah and finally submitted to Sennacherib of Nineveh, Jerusalem was spared.

\section{Yahweh's supremacy over empires: An enduring ideology}

First Isaiah's doctrine that the God of Israel used imperial kings as his agents took hold in prophetic circles, and informed Jeremiah's teachings about a century later in the Neo-Babylonian period. One of the ways of affirming its presence is to trace those passages in Jeremiah where Nebuchadnezzar II, the Babylonian conqueror, is called "צבד "my servant" by the prophet, speaking in the name of Yahweh. The Babylonian king is called "my servant" in Jeremiah 25: $8-14$, in the prophecy of seventy years. Jeremiah states that the God of Israel will give his servant, the king of Babylonia, dominion over many nations. Those who resist will suffer the consequences for seventy years, at which time Babylonia will receive its own delayed punishment from Yahweh. One of those nations that resisted was Judah.

The same theme is presented even more dramatically in a prophecy addressed to several nearby nations, in addition to Zedekiah's Judah, in Jeremiah 27: Whoever fails to submit to Nebuchadnezzar king of Babylonia, "my servant", will suffer war and its terrible consequences. The kings addressed are cautioned not to heed those false prophets and diviners who counsel rebellion. Zedekiah, king of Judah, and the priests and people are specifically admonished in these terms, and told that their only hope for survival is to submit. Nebuchadnezzar is called "my servant" a final time in a prophecy of his destruction of Egypt and its temples in Jeremiah 43: 10, indicating that Jeremiah's doctrine was not applicable only to Israel; it was a world-view.

Between Jeremiah 25 and 27, chapter 26 reports on the trial of Jeremiah for treason, after the prophet had predicted that the Temple and the city of Jerusalem would be destroyed, as Shiloh had been. In the course of the trial, some of the elders reminded the people assembled that Micah of Moreshet Gat had similarly predicted the destruction of Jerusalem in the time of Hezekiah, but instead of condemning him to death, Hezekiah heeded Micah, entreated God, and Jerusalem was spared. We have no record that Micah actually counseled Hezekiah in this manner, although Micah 4: 11-12 states that the nations who had come to despoil Zion failed to comprehend Yahweh's long-term design - עצתו "his plan". This diction resonates clearly with First Isaiah. 
Unfortunately, this time around, Israel did not heed the prophet's words, and Jerusalem was destroyed.

First Isaiah labels conquering Assyria "rod of my rage", and in Jeremiah the God of Israel calls Nebuchadnezzar II, who defeated the Assyrians, "my servant". Both kings devastated Israel, but both were, nevertheless, agents carrying out the God of Israel's international plan. In the later words of Deutero-Isaiah 45, Cyrus the Great, founder of the universal Achemenid empire and conqueror of Babylon, is called, in addition to עבד "my servant" and "mepherd", also "his anointed one". He is viewed as a redeemer, charged by the God of Israel to restore his people and rebuild his temple in Jerusalem (see further below). But the principle is the same: Empires rise and fall, but it is Yahweh of Hosts who grants kings their transient power and retains possession of true kingship. Verses $1-5$ read as follows:

\section{Isaiah 45: 1-5. Yahweh and Cyrus}

Thus said Yahweh to his anointed one, to Cyrus,

Whose right arm I have grasped;

Subduing nations before him, undoing the girded loins of kings;

Opening doors before him, allowing no gates to remain barred.

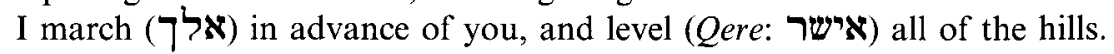

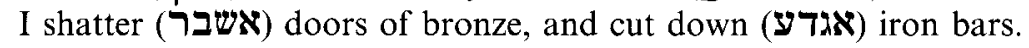

I will give you treasures buried in darkness, the caches of hidden places.

So that you may know that it is I, Yahweh,

Who calls you by your name, the God of Israel.

I have called you by your name;

I entitle you (אכנך) though you do not acknowledge me.

I am Yahweh, and there is no other!

Except for me - there is no divinity!

I empower you (אאזרך) though you do not acknowledge me.

Commentary. The translation given here reflects a particular view of the use of tenses in the prophecy. The six Hebrew verbs in the imperfect tense are taken as present progressives. They describe what is happening, or has been happening, rather than predicting what will occur in the future. There is only one inverted perfect, Hebrew "I will give" (v. 3), and one inverted future "I have called" (v. 4). Yahweh has already called Cyrus by name, a way of saying that he has empowered Cyrus to have dominion over many kings and nations. Yahweh will, pursuant to Cyrus' conquests, grant him untold treasures. This prophecy reflects the situation obtaining during the years following Cyrus' conquest of Babylonia and his exercise of hegemony over Babylonia's former territories, and probably constitutes, in its own way, a fairly immediate response to the Cyrus Edict of 538 BCE. One can deduce as much from Isaiah 44: 26-8, which immediately precedes this prophecy. Yahweh instructs Cyrus, there called רעי "my shepherd", to rebuild Jerusalem and its temple.

On the first level, Isaiah 45: 1-5 reinforces what had been said in First Isaiah and in Jeremiah. The conquests of Cyrus, including the conquest of Judah and Jerusalem from the Neo-Babylonians, are in accordance with Yahweh's plan. There is, however, something new that is conveyed by the title משיח "anointed one" that was not conveyed by the term "sבד "servant", applied to Nebuchadnezzar, or by reference to the Assyrian king as a "rod of rage". Judah's legitimate king is not a scion of the House of David, but rather Cyrus the Great, whose capital is in far-off Persia. This doctrine, most recently discussed by Lizbeth Fried (2004: 179-83), was to have far-reaching consequences, and was not readily accepted by those who hoped for the restoration of the Davidic dynasty.

Hayim Tadmor (1999a) has shed new light on this question, by showing how seriously the prophecy of seventy years, enunciated by Jeremiah, was taken by many of the returning Judean exiles. Their delay in rebuilding the temple, decried by the prophet in the second year of Darius I, may be explained by their strict adherence to the time-frame of seventy years. In their minds, the time specified by Jeremiah had not yet come, as they are quoted in Haggai 1: 2: "The appointed 
time has not yet come, the appointed time for the Temple of Yahweh to be built!' Underlying their resistance may have been an unwillingness to acknowledge a foreign ruler as their legitimate king. That is, of course, the role explicitly envisioned for Cyrus by Deutero-Isaiah (44: 28). As Tadmor explains, a compromise was reached by which Zerubbabel, governor of Judea, a scion of the House of David, was commissioned to rebuild the temple, and a recalculation of the seventyyear time frame was devised to justify avoiding further delay.

The deliberations of the returning exiles indicate that the sovereignty of Yahweh over imperial kings, a concept introduced by First Isaiah in response to the Assyrian threat, continued to function as an operative political ideology in the early post-exilic period. By that time, the last of the Hebrew prophets, Deutero-Isaiah and Trito-Isaiah, Haggai, Zechariah and Malachi, had achieved a long-term, almost apocalyptic view of history, an awareness that empires are transient. Assyria had fallen to Babylonia, and not long after, Babylonia fell to Persia. The gods of Assyria and Babylonia had also fallen.

As for Israel, its "remnant" had returned to Zion under an imperial charter, the Temple of Jerusalem was being rebuilt, and Judean society was being reconstituted in the homeland. The "divine in creation" and the "divine in history", the cosmic and the terrestrial, had been brought into harmony, as the plan of the God of Israel for the whole earth proceeded to unfold. In the words of a late Psalm (113: 3-4):

From the rising of the sun to its setting,

The name of Yahweh be praised!

For Yahweh is supreme over all nations;

His glorious presence is above the heavens.

\section{Acknowledgements}

I am grateful to several scholars who generously shared their knowledge with me at various stages in the progress of this study: Simo Parpola, for his understanding of monotheism in its Assyrian context, Barbara Porter, for her detailed critique of an earlier draft, and most recently Hayim Tadmor, for his valuable insights on the subject of Assyrian ideology. The opportunity to address scholarly audiences was also of great assistance.

\section{References}

Brinkman, J. A. 1964, "Merodach-Baladan II", in Studies Presented to A. Leo Oppenheim, ed. R. D. Biggs et al., Chicago: University of Chicago Press, 6-53.

Brinkman, J. A. 1973. "Sennacherib's Babylonian Problem", Journal of Cuneiform Studies 25: 89-95.

Brinkman, J. A. 1983. "Through a Glass Darkly: Esarhaddon's Retrospects on the Downfall of Babylon", Journal of the American Oriental Society 103: 35-42.

Brinkman, J. A. 1984. Prelude to Empire: Babylonian Society and Politics, 747-626 B.C. (Occasional Publications of the Babylonian Fund 7), Philadelphia: University Museum.

Cogan, M. 1974. Imperialism and Religion (Society of Biblical Literature Series 19), Missoula, MT: Scholars Press.

Cazelles, H. 1992. "Syro-Ephraimite War", in Anchor Bible Dictionary 6: 282-5.

Cohen, Ch. 1979. "Neo-Assyrian Elements in the First Speech of the Biblical Rab-Šaqe", Israel Oriental Studies 9: 32-47.

Cohen, M. (ed.) 1996. MIKRA'OT GEDOLOT 'HAKETER': Isaiah, Ramat Gan: Bar Ilan University, 1996 (in Hebrew).

Dassow, Eva von 2003. By written communication.

Dearman, J. A., Mattingly, G. L. 1992. "Mesha Stele", in Anchor Bible Dictionary 4: 708-9.

Edel, E. 1997. Der Vertrag zwischen Ramses II. von Ägypten und Hattušili III. von Hatti, Berlin: Gebr. Mann.

Finkelstein, I. 1994. "The Archaeology of the Days of Manasseh", in Scripture and Other Artifacts, Essays on the Bible and Archaeology in Honor of Philip J. King, ed. M. D. Coogan et al., Louisville, KY: Westminster/John Knox Press.

Frahm, Eckart 1997. Einleitung in die Sanherib-Inschriften (Archiv für Orientforschung Beiheft 26), Vienna: Institut für Orientalistik der Universität Wien.

Fried, Lisbeth S. 2004. The Priest and the Great King, Winona Lake, IN: Eisenbrauns.

George, A. R. 1986. "Sennacherib and the Tablet of Destinies", Iraq 48: 133-46.

Gitin, S. et al. 1997. “A Royal Dedicatory Inscription from Ekron", Israel Exploration Journal 47: 1-16.

Goelet, O., Levine B. A. 1998. "Making Peace in Heaven and on Earth: Religious and Legal Aspects of the Treaty between Rameses II and Hattušili III", in Boundaries of the Ancient Near Eastern World, ed. M. Lubetsky et al. (Journal for the Study of the Old Testament Supplement 273), Sheffield, 252-99. 
Gray, G. B. 1912. The Book of Isaiah, I-XXXIX, International Critical Commentary, Edinburgh: T. \& T. Clark.

Grayson, A. K. 1992. "Sennacherib", in Anchor Bible Dictionary 5: 1088-9.

Hoftijzer, J., Jongeling, K. (eds.) 1995. Dictionary of the North-West Semitic Inscriptions, Leiden: Brill.

Hornung, E. 1982. Conceptions of God in Ancient Egypt: The One and the Many, trans. J. Baines, Ithaca, NY: Cornell University Press.

Horowitz, W. 1998. Mesopotamian Cosmic Geography, Winona Lake, IN: Eisenbrauns.

Jacobsen, Th. 1946. "Mesopotamia: The Cosmos as a State, the Function of the State, the Good Life", in The Intellectual Adventure of Ancient Man, ed. H. Frankfort et al., Chicago: University of Chicago Press, 125-219.

Jacobsen, Th. 1963. "Ancient Mesopotamian Religion: The Central Concerns", in Cuneiform Studies and the History of Civilization (Proceedings of the American Philosophical Society 107), Philadelphia: American Philosophical Society, 473-84.

Lang, B. 2003. "Die Jahwe-allein-Bewegung: Neue Erwägungen über die Anfänge des biblischen Monotheismus", in Der eine Gott und die Götter: Polytheismus und Monotheismus in antiken Israel, ed. M. Oeming, K. Schmid, Zurich: Theologischer Verlag, 97-110.

Levine, Baruch A. 1974. In the Presence of the Lord, Leiden: Brill.

Levine, Baruch A. 1996. "What's in a name?' The Onomasticon of the Biblical Record and the Religious Beliefs of Israelites", Eretz-Israel 25 (Joseph Aviram Volume), Jerusalem: Israel Exploration Society, 202-9 (in Hebrew).

Levine, Baruch A. 2003. "Ah, Assyria, Rod of My Rage' (Isa 10: 5): Biblical Monotheism as Seen in an International Political Perspective: A Prolegomenon", Eretz-Israel 27, Jerusalem: Israel Exploration Society, 136-42 (in Hebrew).

Levine, Baruch A. 2003a. "'Weihe, Aššur, Rute meines Zorns!' Der biblische Monotheismus als Antwort auf die neue politische Realität des assyrischen Weltreiches", in Der eine Gott und die Götter, ed. M. Oeming, K. Schmid, Zurich: Theologischer Verlag Zurich, 77-96.

Liverani, M. 1979. "The Ideology of the Assyrian Empire", in Power and Propaganda: A Symposium on Ancient Empires, ed. M. T. Larsen (Mesopotamia 7), Copenhagen: Akademisk Forlag, 297-317.

Liverani, M. 1981. "Critique of Variants and the Titulary of Sennacherib", in Assyrian Royal Inscriptions: New Horizons in Literary, Ideological and Historical Analysis, ed. F. M. Fales (Orientis Antiqui Collectio 17), Rome: Istituto per l'Oriente, 225-57.

Liverani, M. 2001. "The Sargon Geography and the Late Assyrian Mensuration of the Earth, State Archives of Assyria Bulletin 13: 57-85.

Luckenbill, D. D. 1924. The Annals of Sennacherib, Chicago: University of Chicago Press.

Machinist, P. 1976. "Literature as Politics: The Tukulti-Ninurta Epic and the Bible", Catholic Biblical Quarterly 38, 455-82.

Machinist, P. 1983. "Assyria and its Image in the First Isaiah", Journal of the American Oriental Society 103: 719-37.

Mettinger, T. 1979. "The Veto on Images and the Aniconic God in Ancient Israel", in Religious Symbols and their Functions, ed. H. Biezais, Stockholm: Almquist \& Wicksell International, 15-29

Müller, Karl Fr. 1937. Das assyrische Ritual, Texte zum assyrischen Königsritual (Mitteilungen der vorderasiatisch-ägyptischen Gesellschaft 41/3), Leipzig

Olyan, S. 1988. Asherah and the Cult of Yahweh in Israel (Society of Biblical Literature Monograph Series 34), Atlanta: Scholars Press.

Parpola, S. 1997. Assyrian Prophecies (State Archives of Assyria 9), Helsinki: Helsinki University Press.

Porter, B. N. 2000. "The Anxiety of Multiplicity: Concepts of Divinity as One and Many in Ancient Assyria", in One God or Many? Concepts of Divinity in the Ancient World, ed. B. N. Porter, Bethesda, MD: CDL Press, 211-71.

Saggs, H. W. F. 1978. The Encounter with the Divine in Mesopotamia and Israel, London: Athlone Press.

Schoors, A. 1997. "Historical Information in Isaiah 1-39", in Studies in the Book of Isaiah (Fs Willem A. M. Beuken), ed. J. van Ruiten, M. Vervenne, Leuven: Leuven University Press, 75-93.

Smith, Mark S. 1991. The Early History of God, San Francisco: Harper and Row.

Smith, Mark S. 2001. The Origins of Biblical Monotheism, Oxford: Oxford University Press.

Smith, Morton 1971. Palestinian Parties and Politics that Shaped the Old Testament, New York: Columbia University Press.

Tadmor, H. 1981. "History and Ideology in the Assyrian Royal Inscriptions", in Assyrian Royal Inscriptions: New Horizons in Literary, Ideological and Historical Analysis, ed. F. M. Fales (Orientis Antiqui Collectio 17), Rome: Istituto per l'Oriente, 13-33.

Tadmor, H. 1982. "Treaty and Oath in the Ancient Near East: A Historian's Approach", in Humanizing America's Iconic Book: Society of Biblical Literature Centennial Addresses 1980, ed. G. M Tucker, D. A. Knight, Chico, CA: Scholar's Press, 127-52.

Tadmor, H. 1986. "Sennacherib's Campaign in Judah", Zion 50: 66-80 (in Hebrew).

Tadmor, H. 1989. "The Sin of Sargon and Sennacherib's Last Will, Part II: The Historical Background" [1958], State Archives of Assyria Bulletin 3: 25-32. 
Tadmor, H. 1994. The Inscriptions of Tiglath-Pileser III, King of Assyria, Jerusalem: Israel Academy of Sciences and Humanities.

Tadmor, H. 1999. "World Dominion: The Expanding Horizon of the Assyrian Empire", in Landscapes: Territories, Frontiers and Horizons in the Ancient Near East, ed. L. Milano et al. (RAI 44, 1997), Padua: Sargon srl, 55-62.

Tadmor, H. 1999a. “'The Appointed Time Has Not Yet Arrived': The Historical Background of Haggai 1: 2", In Ki Baruch Hu: Ancient Near Eastern, Biblical, and Judaic Studies in Honor of Baruch A. Levine, ed. R. Chazan et al., Winona Lake, IN: Eisenbrauns, 401-8.

TANAKH 1985. TANAKH: A New Translation of the Holy Scriptures, Philadelphia: Jewish Publication Society, 1985.

Weippert, M. 1972. "Heiliger Krieg' in Israel und Assyrien”, Zeitschrift für die alttestamentliche Wissenschaft 84: 460-93.

Weippert, M. 2002. “König, fürchte dich nicht!' Assyrische Prophetie in 7. Jahrhundert v. Chr.”, Orientalia 71: $1-54$. 